\title{
Importance of Process Management in Business Excellence
}

\author{
Norailis Ab. Wahab and Rosnia Masruki
}

\begin{abstract}
Over the past decades, the pursuit of business life has been extended to excel in every way as a competitive advantage. Since its inception, Malcolm Baldrige National Quality Awards (MBNQA) has assisted organizations in managing as well as reviewing seven dimensions which are leadership, planning, information, customer, people, process and results that are related to business sustainability. Therefore, the objectives of this paper is to explore the literature on business excellence (BE) in various industries. Secondly, to share the experiences of two Indonesian companies that involve with BE in their journey which concern more on process management in work environment. There were evidence that MBNQA has been a great tool for those voluntary companies. In fact, Indonesian State-Owned Enterprises (BUMN) as the government representative has to manage of wealth in the country and to monitor the performance of the government enterprises strongly encouraged of those enterprises and its subsidiaries in implementing BE. The success of the implementation could be seen in their past years performance at the international level.
\end{abstract}

Keywords-Business Excellence, process management, Indonesia, results.

\section{INTRODUCTION}

B USINESS excellence (BE) is much more than having a quality system in place. It is about achieving excellence in everything including leadership, strategy, customer focus, information management, people and processes and most importantly achieving superior business results. BE models were first called Total Quality Management models. This model is now used in countries across the globe as a key mechanism to help businesses to assess their strengths, areas for improvement and guide them on what to do further. It also has the potential to provide management with a holistic method with which to manage businesses and get buy-in to key decisions that will lead to sustainable and measurable successes that are aligned to the organization's objectives and take into account current thought on best practices.

\section{II.LITERATURE REVIEW}

[1]-[5] emphasized on effective and efficient human resource management for business excellence in various organizations. On top of that, [6] drew attention in utilizing

Norailis Ab. Wahab is with the Islamic Finance and Wealth Management Institute (IFWMI), Universiti Sains Islam Malaysia, 71800 Nilai, MALAYSIA. (corresponding author's phone: 00606 7986376; e-mail: norailis@usim.edu.my).

Rosnia Masruki is with the Faculty of Economics and Muamalat, Universiti Sains Islam Malaysia, 71800 Nilai, MALAYSIA. (e-mail: rosnia@usim.edu.my). human resources among the most rated motives for the recipient of European Quality Award. [1] mentioned that organizations have to strategize in utilizing their workforce to the maximum potential. In fact, it is important to focus on human resource issues for quality strategy formulation and implementations [6].

BE meant "excellence" in strategies, business practices, and stakeholder-related performance results that have been validated by assessments based on specific models proven to support the challenging journey towards excellence [7]. In addition, $\mathrm{BE}$ is a comprehensive management practices standard developed to assist companies assesses readiness and compliance to excellence practices in their quest to enhance business performance. BE had been used by many international organizations to evaluate and benchmark of excellent practices and recognize the attainment of this standard. The first BE model was developed in the mid-1980s and came about as result of the quality movement in the West, which in turn was a response to the advancements in quality and competitiveness in Japan [7]. Over time, the term "Business Excellence" started to replace the terms "Quality" and "TQM". Today, many countries employ BE such as EFQM Model, The Australian Model and TQM as a key mechanism for improving the performance of organizations, as well as national competitiveness. The most popular and influential model called the Malcolm Baldrige Award Model (commonly known as the Baldrige model, the Baldrige criteria, or the Malcolm Baldrige Criteria for Performance Excellence). More than 60 national and state awards based their frameworks upon the Baldrige criteria.

The Baldrige model provides a systems perspective for understanding performance management and reflects validated, leading-edge management practices against which an organization can measure itself. With their acceptance nationally and internationally as referential model for performance excellence, the Baldrige criteria represent a common language for communication among organizations for sharing best practices and designed to help organization improve their competitiveness by focusing on two goals: continually delivering value to customers, and improving overall organizational performance. On top of that, three important roles of the Baldrige model are to help improve organizational performance practices, capabilities and results, to facilitate communication and sharing of best-practices information among and within organization of all types, to serve as a working tool for understanding and managing performance, and for planning and opportunities for learning. 


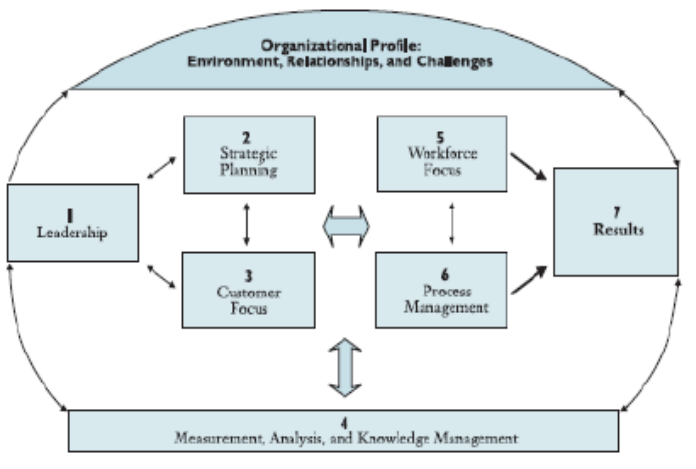

Fig 1: Malcolm Baldrige Criteria for Performance Excellence

The Baldrige criteria framework which illustrated in Fig 1 includes seven categories: leadership; strategic planning; customer and market focus; measurement, analysis and knowledge management, human resources focus; process management; and business results. The Baldrige framework ensures continuous improvement in delivering products and/or services, demonstrates efficient and effective operations, and provides a way of engaging and responding to customers and other stakeholders. Those continuous improvements help the company to receive the awards not due of specific products or services.

Previous scholars stated that BE models are still evolving from measures perspective due to changing demand of today's business landscape [1], [8]-[16]. Moreover, there are higher ignorance among organizations of their national excellence framework [17] but the concern from governments are increasing as the value besides being sustainable is significant [5]. By promoting benchmarking among BE practitioners, it provides operational insights concerning problematic areas in businesses [18], [19]. The link of BE initiatives and its variance in outcomes is understudied [20]. In addition, there are internal and external issues as barriers to long-term commitment towards business excellence. However, it can be overcome by greater promotion of identified enablers including better education, training and higher senior management involvement [21]. Furthermore, BE also supports other quality initiatives but it should be well understood [22], [23].

Realizing the importance of businesses to the nation, it is best if it has a structured programme that encompasses important core values. Therefore, the authors aimed to achieve these objectives through this paper by: comparing the practices among organizations; and exploring the importance of that workforce pillar to businesses in Indonesia.

\section{Methodology}

The authors required different types of information that qualitative studies can provide which is rich in detail. Thus, the information was gathered through in-depth interviews as an interpretative approach with three businesses that were listed under Indonesian State-Owned Enterprises (BUMN). Those businesses existed nearly two decades. Interviews were conducted at their own premises that lasted for an average of one hour. A recorder was used to facilitate the interviews as well as comprehensive notes of the answers. The results of each interview were transcribed immediately after each session. Initially, to crystallize the responses, further analysis using NVivo software mainly involved the data with the aim of identifying and classifying feedbacks regarding the abovementioned objectives. The results of interviews and its discussion will be elaborated by points in the following section.

\section{A. PT Krakatau Steel (PTKS)}

On $31^{\text {st }}$ August 1970, PTKS was established by utilizing materials of Trikora Iron Steel Project such as steel wire mill, steel bar mill and steel section mill plants. In 1987, it shown its significant development when the company added its production facilities such as Sponge Iron Plant, Steel Billet Plant, and Wire Rod Plant. Besides that, the company also added infrastructure facilities of electricity power, Water Treatment Plant, Cigading Special Port and telecommunication system to their rank. This leads PTKS to become the only integrated steel company in Indonesia. The company continued to develop the production of various steel products for various uses, such as hot and cold rolled coils as well as wire rods. Through its ten subsidiaries, PTKS is able to diversify business to support its operation, such as high-addedvalue steel production, utility industry, port and industrial estate, Engineering Procurement and Construction services, information technology and hospitals.

\section{B. PT Wijaya Karya (WIKA)}

In the early 1960s, WIKA's line of business at the time was electrical and water pipe installation works. With the passing of time, various improvements were made in order to continue growing as well as contribute to nation-building by providing construction services throughout the country. The first significant growth occurred in 1972, when the name Perusahaan Negara Widjaja Karja was changed to PT Wijaya Karya. WIKA then developed into a construction contractor by handling various important projects such as the installation of electricity grids at Asahan and the Jatiluhur irrigation project.

A decade later, in 1982, WIKA underwent expansion with the establishment of several new divisions, namely the Construction Civil Division, Building Division, Housing Facilities Division, Concrete and Metal Products Division, Industrial Construction Division, Energy Division, and Commerce Division. Moreover, with the progressive growth of its subsidiaries in the industrial sector WIKA was transformed into an integrated and synergetic infrastructure company.

The skills of WIKA personnel in the construction industry have pushed the company to further explore the various areas in which it does business by establishing a number of subsidiaries in order that they can become independent as business ventures that specializes in creating their own respective products. In the mid of 2009, WIKA has succeeded 
in completing the Suramadu Bridge, a prestigious project that connects Java and Madura islands. Currently the project have been enjoyed by the community at large.

\section{FINDINGS AND DISCUSSION}

\section{A. PT Krakatau Steel (PTKS)}

Competency Management helps PTKS to determine process of requirements to meet their objectives and define potential owned by the organization. It also helps to develop strategies for recruitment or internal development based on the competency level requirement.

It is PTKS's policy to ensure the occupational safety, health and environment of all employees is by implementing the occupational safety, health and environment management system, fulfilling applicable laws and regulations, and conducting sustained improvement.

In environment management, PTKS has implemented various waste management, emission and resources policy to prevent negative impact on environment. The organization also has created a healthy and safe working environment by implementing occupational accident and health problems prevention methods.

The aims of occupational safety and health management in PTKS are not only to protect its employees and other people in working area, but also to guarantee smooth processes of production. PTKS realizes that implementation of occupational safety (e.g. OHSAS 18001:2007), health and environment requires understanding and continuous socializations to the employees. Therefore, the company takes some efforts to improve employees' awareness, knowledge and competence in occupational environment, safety and health, through publications, information disseminations and trainings.

Occupational Safety and Health includes occupational health services, health cost management program, insurance program, risk identification and risk assessment program, working environment evaluation and monitoring program and working accident prevention program. Implemented occupational health services consist of prior to work, periodic (once a year) and special health monitoring. The Company also conducts assistance and monitoring working adjustment of employee, particularly those with special needs, environment and sanitation improvement and monitoring, general and occupational disease prevention, first aid, preventive measure activities in the form employee health education and training, nutrient consumption assistance and monitoring, and medical rehabilitation and occupational.

From the environment perspective, PTKS has set a long term vision that is "To be a Leading Green and Environmental Friendly Industry". For the realization of those policies and vision, they has included all to the standard operating procedure, Quality Objective, Clean Production Program (at PTKS 5R), guidelines/manual and work rules. Those tools/means are coordinated into the environment management system ISO14001 and K3 management system (are comply to SMK3 \& OHSAS 18001) which has been implemented integrally and consistently at PTKS since 1997. Their activities in environmental management includes Environmental Management Program, which consists of air and water pollution control, B-3 and non-B-3 waste management, reforestation, sea conservation, zero waste concept; Environmental Monitoring Program monitors the air emission of factory's chimney, ambient air quality, environmental noise level, the dust concentration in factory area, working climate, water waste quality, water stream and sea. Monitoring based on the environmental standard quality is conducted periodically by internal and independent bodies.

PTKS also has resources conservation program includes the utilization efficiency of natural resources and energy to prevent their availability and sustainability. This resources conservation consists of substitution of material and emission utilization, hot-waste utilization, $\mathrm{CO} 2$ waste utilization to become industrial gas. The company's commitment in environmental management has impacted on the performance.

As the result of the above mentioned practices, PTKS became the domestic market leader, in particular for hot and cold rolled coil product. It dominated market share as $41 \%$ and $24 \%$ for hot and cold rolled coil respectively. While wire rods product is on second position with $25 \%$ of market share. PTKS's environmental management has brought in a lot of achievements and recognitions as follows.

i. The ISO 14001 certificate awarded in 1997 and is still maintained.

ii. Maintaining the PROPER BIRU achievement in 2011 which was the performance measurement for the Company in environmental field from the Ministry of the Environment, and the Company's image is performed well for those achievements.

iii. Awarded as the third best in Green and Environmental Insight Industry for State-owned Enterprise category from the Minister of Industry in March 2010.

Meanwhile, the Safety Management also succeeds in reducing the number of accident by $49 \%$. PTKS had been awarded Customer Brand Choice Award 2011 from Markplus $\&$ Co.

\section{B. PT Wijaya Karya (WIKA)}

WIKA have implement Indonesian National Standards as well as for awareness of the development of standards, and good performance. The award receive is proof of the consistency in implementing standards. Company experts participate actively in the national mirror committee to ISO/TC 71. In addition, during operation, WIKA cares for the occupational health, safety and environment (OHSE). In line with WIKA's mission, the company implement a management system in OHS, which is the OHSAS 18001:2007. In addition, WIKA also have implemented the national standard on Management System of Occupational Health and Safety from the Workforce and Transmigration Ministry since 2003.

On some projects, WIKA has also implemented the DuPont Safety System to enhance the compliance on OSH and formed Site Implementation Team (SIT). SIT engages all project managements to implement OHSE regulations.

WIKA pays attention to employees who work on construction projects due of high risks in facing threats of 
OSH. Due of that, WIKA provide self-protection devices and require every employee to wear them when working or being in construction project.

Furthermore, WIKA also implement quality management system, which based on ISO 9001 which the operations of different business functions were integrated and optimized. Particularly relevant are the time savings in the engineering business function due to the dissemination of standardized information (e.g. for material specifications, process specifications and standardization of the product). This information is also used to define better working instructions and operational procedures, leading to the increased efficiency of several production processes. Such developments have also helped to achieve higher product quality, boosting both customer confidence and sales revenue.

In 2013, WIKA experienced a significant improvement on its financial performances. WIKA recorded an increased net sales by $16.66 \%$ from the previous year that reached $\mathrm{Rp} 9.905$ million to Rp11.885 billion. While sales of Joint Venture by $23.16 \%$ from previous year that reached $\mathrm{Rp} 2.438$ million to Rp3.173 million in 2013. The total sales of WIKA in 2013 reached 15.059 million, increased by $18.03 \%$ from the previous year that only reached Rp12.343 million. The gross profit after joint venture in 2013 increased by $26.58 \%$ to Rp1.58 million from Rp.1.16 million in 2012. The net income also have increase by $16 \%$ from Rp526,27 billion to Rp624,37 billion.

Improvement of those total assets and gross profit were supported by the new contracts and Order Book in the field of construction, industry, real estate, mining and electrical mechanism. The Order Book in 2013 was Rp38.267 billion, increased by $13.49 \%$ from 2012 that was only Rp33.718 billion.

The sustainability activities that done by WIKA have made steady favorable results on employee perceptions of leadership's ethical behavior. As results, WIKA have received awards; BUMN \& CEO BUMN Award - 3rd Best CEO 2005, Top 1 CEO Category 2006, The Best CEO 2008 by Swa Leadership Forum, Aon Hewitt Consulting - The Best Employer 2011, The Best Employer 2011 by BUMN, Aon Hewitt - Best Employer Indonesia 2013, Performing Construction CEO 2013 by Warta Ekonomi, and Indonesian Most Admired CEO 2014.

By implementing OHSAS 18000:2007, WIKA has enabled to reduce the number of occupational hazards in 2013. In fact on some construction projects, the firm has successfully achieved zero-accidents so that many other parties have shown their appreciations (see Fig 2). As results, WIKA have received awards Safety and Environment Award 2010 by Mitsubishi Corporation- Tanjong Priok GFPPEP 740 MW, Best EHS Performance for Subcontractors 2009 by PT Areva $\mathrm{T} \& \mathrm{D}$.

The 2012 Good Corporate Governance (GCG) assessment was conducted by an independent party which is the Indonesian Institute for Corporate Governance (IICG) using the Corporate Governance Perception Index, in 2013, the score was 80.36 which means that the company belongs to the category of 'Indonesia Trusted Companies'. While, for the 2013 GCG assessment will be carried out by BPKP (Financial and Development Supervisory Agency in 2014 (WIKA, 2013).
As result, WIKA was the Trusted Company Based on Corporate Governance Perception Index (CGPI) 2013. WIKA also have been awarded The Best in Building and Managing Corporate Image 2014 by Frontier Consulting Group, Bloomberg Business Week Magazine \& Corporate Image (IMAC) Committee, and IICD Corporate Governance Award 2010 by IICD.

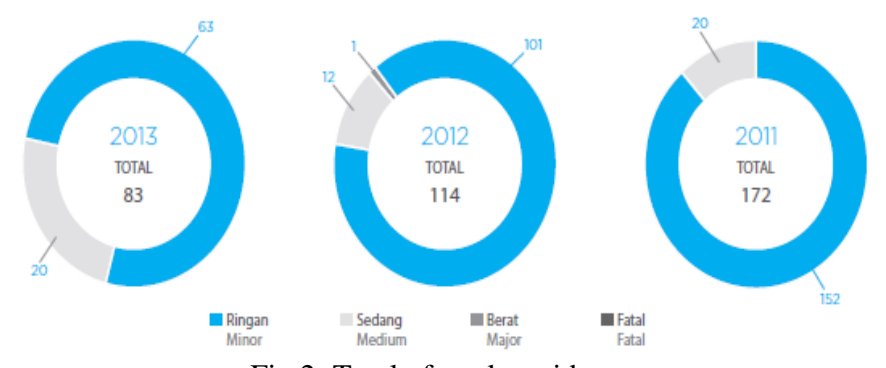

Fig 2: Total of work accidents

\section{V.CONCLUSION}

Enforcement of BE by Indonesian State-Owned Enterprises (BUMN) is a good practice to ensure business continuity. These companies has been implementing BE as guidance in enhancing its competitiveness and excellences in all of their operation. Through BE, they were able to manage and measure performances not only in business result but also in all business processes. BE provides healthy competition to achieve their vision and be a role model to other businesses. From the economic aspect, customer demand, human resources management, and process are difficult for many companies today to meet their requirement. However, the two cases have proven that by utilizing the processes and tools from BE they are able to not only meet these challenges but actually excel in them and continuously improves.

\section{ACKNOWLEDGMENT}

This paper was supported by Malaysia Productivity Corporation (MPC) for the insight and expertise that greatly assisted during the writing progress.

\section{REFERENCES}

[1] Talwar, B. (2011). Comparative study of framework, criteria and criterion weighting of excellence models. Measuring Business Excellence, Vol. 15 Iss: 1, pp.49-65. https://doi.org/10.1108/13683041111113240

[2] Politis, Y., Litos, C., Grigoroudis, E. And Moustakis, V.S. (2009). A business excellence model for the hotel sector: implementation to highclass Greek hotels. Benchmarking: An International Journal, Vol. 16 Iss: 4, pp. $462-483$. https://doi.org/10.1108/14635770910972414

[3] Dahlgaard-Park, S.M. (2009). Decoding the code of excellence - for achieving sustainable excellence. International Journal of Quality and Service Sciences, Vol. 1 Iss: 1, pp.5 - 28.

https://doi.org/10.1108/17566690910945840

[4] Mele, C. And Colurcio, M. (2006). The evolving path of TQM: Towards business excellence and stakeholder value. International Journal of Quality \& Reliability Management, Vol. 23 Iss: 5, pp.464 - 489. https://doi.org/10.1108/02656710610664569

[5] Zhao, F. (2004). Siemens' business excellence model and sustainable development. Measuring Business Excellence, Vol. 8 Iss: 2, pp.55 - 64. https://doi.org/10.1108/13683040410539436 
[6] Vouzas, F.K. and Gotzamani, K.D. (2005). Best practices of selected Greek organizations on their road to business excellence: The contribution of the new ISO 9000:2000 series of standards. The TQM Magazine, Vol. 17 Iss: 3, pp.259-266.

https://doi.org/10.1108/09544780510594225

[7] Ionică A., Băleanu, V., Edelhauser, E. and Irimie, S. (2010). TQM And Business Excellence. Annals of the University of Petrosani, Economics, University of Petrosani, Romania, vol. 10(4), pages 125-134.

[8] Enquist, B., Johnson, M. and Ronnback, A. (2015). The paradigm shift to Business Excellence 2.0. International Journal of Quality and Service Sciences, Vol. 7 Iss: 2/3, pp.321 - 333. https://doi.org/10.1108/IJQSS-03-2015-0032

[9] Bolboli, S.A. and Reiche, M. (2013). A model for sustainable business excellence: Implementation and the roadmap. The TQM Journal, Vol. 25 Iss: 4 , pp. $331-346$. https://doi.org/10.1108/17542731311314845

[10] Talwar, B. (2011b). Business excellence models and the path ahead ... The TQM Journal, Vol. 23 Iss: 1, pp.21 - 35. https://doi.org/10.1108/17542731111097461

[11] Antony, J.P. and Bhattacharyya, S. (2010). Measuring organizational performance and organizational excellence of SMEs - Part 1: A conceptual framework. Measuring Business Excellence, Vol. 14 Iss: 2, pp.3 - 11 . https://doi.org/10.1108/13683041011047812

[12] Angell, L.C. and Corbett, L.M. (2009). The quest for business excellence: Evidence from New Zealand's award winners. International Journal of Operations \& Production Management, Vol. 29 Iss: 2, pp.170 $-199$. https://doi.org/10.1108/01443570910932048

[13] Saunders, M., Mann, R.S. and Grigg, N.P. (2008). Utilisation of business excellence models: Australian and international experience. The TQM Magazine, vol.20 no.6 pp.651-663. https://doi.org/10.1108/17542730810909392

[14] Klefsjo, B., Bergquist, B. And Garvare, R. (2008). Quality management and business excellence, customers and stakeholders: Do we agree on what we are talking about, and does it matter?. The TQM Journal, vol.20 Iss. 2 pp.120.129. https://doi.org/10.1108/17542730810857354

[15] Harrington, H.J. (2005). The five pillars of organizational excellence. Handbook of Business Strategy, Vol. 6 Iss: 1, pp.107 - 114. https://doi.org/10.1108/08944310510557116

[16] Garvare, R. And Isaksson, R. (2001). Sustainable development: Extending the scope of business excellence models. Measuring Business Excellence, Vol. 5 Iss: 3, pp.11 - 15. https://doi.org/10.1108/13683040110403899

[17] Grigg, N. And Mann, R. (2008). Promoting excellence: An international study into creating awareness of business excellence models. The TQM Journal, Vol. 20 Iss: 3, pp.233 - 248. https://doi.org/10.1108/17542730810867254

[18] Antony, J.P. and Bhattacharyya, S. (2010b). Measuring organizational performance and organizational excellence of SMEs - Part 2: an empirical study on SMEs in India. Measuring Business Excellence, Vol. 14 Iss: 3 , pp. $42-52$. https://doi.org/10.1108/13683041011074209

[19] Bilalis, N., Alvizos, E., Tsironis, L. and Wassenhove, L.v. (2007). Benchmarking the competitiveness of industrial sectors: Application in textiles. International Journal of Productivity and Performance Management, Vol. 56 Iss: 7, pp.603 - 622. https://doi.org/10.1108/17410400710823642

[20] Meers, A. and Samson, D. (2003). Business excellence initiatives: dependencies along the implementation path. Measuring Business Excellence, Vol. 7 Iss: 2, pp.66 - 77. https://doi.org/10.1108/13683040310478002

[21] Mann, R., Adebanjo, D. and Tickle, M. (2011). Deployment of business excellence in Asia: An exploratory study. International Journal of Quality \& Reliability Management, Vol. 28 Iss: 6, pp.604 - 627. https://doi.org/10.1108/02656711111141184

[22] Boys, K., Wilcock, A., Karapetrovic and Aung, M. (2005). Evolution towards excellence: Use of business excellence programs by Canadian organizations. Measuring Business Excellence, Vol. 9 Iss: 4, pp.4 - 15. https://doi.org/10.1108/13683040510634790

[23] Adebanjo, D. (2001). TQM and business excellence: Is there really a conflict?. Measuring Business Excellence, Vol. 5 Iss: 3, pp.37 - 40. https://doi.org/10.1108/13683040110403961

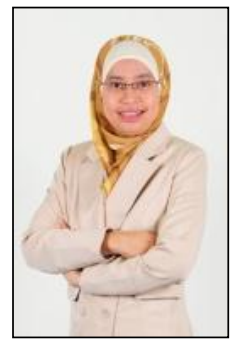

Norailis A.Wahab graduated from Faculty of Economics, Universiti Kebangsaan Malaysia in 2000. She obtained her Master Degree in Productivity and Quality Enhancement a year later. In 2009, she has been conferred a Doctoral Degree (Quality Management) from the University of Stirling, Scotland.

Dr Norailis led several research teams and guided a group of $\mathrm{PhD}$ students under her supervision that focused on benchmarking, human resource, halal industry plus other areas of business and management. Appointment as a Research Fellow at Islamic Finance and Wealth Management Institute (IFWMI) and Institute of Halal Research and Management (IHRAM) encouraged her to involve actively in trainings, research and publications that are related to the usage of NVivo software. Cases write-ups is becoming her new passion lately. Several of those cases were published by Penerbit USIM and Institut Maklumat dan Pasaran Buruh (ILMIA), Ministry of Human Resources. Presently, she is actively engage with activities organized by SME Corporation (SME Corp), Malaysia Productivity Corporation (MPC) and UKM-Yunus CASB.

She is a Business Excellence Assessor appointed by MPC since 2014, a life member of Malaysian Muamalat Association (MMA) and The Malaysian Consumer and Family Economics Association (MACFEA). She joined SME Corp for three months in 2012 to gain industrial experiences. At the same time, she put effort in establishing engagement with practitioners in small and medium enterprises as well as external consultants in Muslim Coaches Association of Malaysia (MCAM). Since 2014, she became one of the panels for Industry Excellence Award and Malaysia Franchise Award. 